\title{
EFFECT OF CATECHOLAMINE PRECURSORS AND \\ PHENYLETHYLAMINES ON SPONTANEOUS ACTIVITY AND ON THE RESPONSE TO METHOHEXITAL ANAESTHESIA*
}

Peter $\mathbb{K}$ Y Lee, Md, Min $\mathbb{H}$ Cho, Mi , phd, and Alten B Dobrin, mD

Science is bult up by successive solutions given to questions of incieasing subtlety, approaching neaier and neaser towards the very essence of phenomena

Louis Pasteun, Etudes sur la Bière

SINCE von Euler established the functions of epınephrine and norepinephrine as adrenergic transmitters and with the finding of another tissue catecholaminedopamine-which is a precursor of the first two, a great deal of interest has developed surrounding the pressor and psychic effects of these substances It is now quite clear that epinephrine acts primanly as a hormone in the body, while norepinephrine, which is an intermediate of epinephrine formation, acts as a hormone also but is a nervous transmitter as well and is perhaps the most important substance in the body with respect to control of the cardiovascular system The function of dopamine, aside from its role as an intermediate of norepinephrine formation, is not yet clear, although one may suspect that it has a physiological function of its own ${ }^{1}$

In the past decade, the endogenous catecholammes have been identified as the main substances in the body which can prevent or counteract the deleterious effects of some anaesthetics on the cardiovascular system, whlle they have been known to cause serious cardiac disturbances with other anaesthetics ${ }^{23}$ During this pei 1od, work has also been directed towards determining whether epinephrine and/or some of its precursors play a role in the aetiology of psychomotor disilurbances, but the information in this field is still confusing ${ }^{4-6}$

Variations in the concentration of circulating catecholamines and changes produced in the arterial blood pressure by these also appear to influence the activily of the facilitatory and inhibitory portions of the reticular formation of the brain stem, which has a direct influence on wakiefulness ${ }^{7} 8$ These influences have heen studied specifically by recording the electrical activity of the spinal motor neuron on preparations with brain stem sections at different levels ${ }^{9}$ These experiments demonstrated that after premammilary transection of the brain the intravenous injection of epinephrine always produces a considerable facilitation of the monosynaptic reflex, of the spontaneous activity of the motor neuron, and less regularly, of the polysynaptic reflex This facilitation no longer occurs after retromammilary transection of the brain and is abolished also by anaesthetic agents After retropontine transection, the same injection of epinephrine produces a rapid and profound inhibition of the monosynapic and polysynaptic reflexes

*From the Department of Anesthesiology, State University of New York, Upstate Medical Center, Syracuse, New York, 13210 Supported in part by USPHS Grant NB-03809-03 
and of the spontaneous activity of the motor neuron This inhibitory effect is replaced by facilitation when the roots of the IXth and Xth cranial nerves are sectioned intracranially to elimmate the inflow of afferent impulses from the pressoreceptors in the carotid sinus and the aorta Thus, it appears that an increase in the activity of the sympathetic nervous system acts in two distunct and antagonistic ways upon the reticular formation The arterial hypertension associated with an increased concentration of circulating epinephrine may inhibit the spinal motor neuron This inhibition depends upon discharges originating in the pressoreceptors, which directly activate the bulbar inhibitory portion of the reticular formation This is a reflex mechanis.n acting in a tonic way "The increase of concentration of circulating epinephrine also produces a facilitation of the spinal motricity which is essentially mediated by the reticular facilitatory formations localized in the anterior part of the bram stem The fact that certain reticular neurons are sensitive to epinephrine is important in view of Vogt's observation that the hypothalamus is rich in catecholammes (mainly norepmephrine) ${ }^{7}$ The functional significance of the two antagonistic effects of epinephrme upon the brain stem is also important when considering the different physiological situations in which a peripheral sympathetic discharge occurs, as in emotional states, muscular effort, and various forms of physiological stress The excitatory action of epinephrine exerting its effects upon the reticulocortical and the reticulospinal system considerably heightens the level of activity of the whole somatic system The counterregulation exerted by the pressoreceptors acting by way of the inhibitory bulbar portion of the reticular formation keeps in check the output of the muscular apparatus and co-ordinates its activity with the capacity of the circulatory system According to Dell and associates, this humoral co-ordination between somatic and vegetative activities discloses the existence within the nervous system of integrative processes which have a biochemical basis ${ }^{9}$

Ingvar and Soderberg have studied the intumate correlation which exists between the cerebral blood flow, systemic blood pressure, and the electncal activity of the cortex of the brain as reflected by the $\mathbb{E} \mathbb{E} \mathbb{G}^{10}$ They showed that arousing stimuli which activate the $\mathbb{E} \mathbb{E}$ are associated with a marked increase in the cerebral blood flow which is independent of changes in the systemic blood pressure Spontaneous changes in cerebral blood flow accompanied by changes in the $\mathbb{E} \mathbb{E} G$ were also observed to occur in the lightly anaesthetized anmal Small doses of anaesthehc agents, sufficient to induce a sleep pattern of the $\mathbb{E} G$ and a block of the arousal reaction, paralyse the mechanisms regulating cerebral vasomotor tone They also found that during deep barbiturate anaesthesia the cerebral vessels are much more constricted than under light ether anaesthesia In general, autonomic mechanisms are very sensitive to anaesthesia, causing alterations in pupillary diameter and loss of tone of cutaneous vessels, whereas, during arousal, cutaneous vasoconstriction develops and the pupils constrict On the other hand, autonomic mechanisms which regulate systemic blood pressure are rather insensitive to deep anaesthesia since an arousal reaction in the $\mathbb{E} \mathbb{G}$ does not appear with nociceptrve stimulation even though a passive change in cerebral blood flow does occur

Brodie and associates beheve that many of the lipid soluble congeners of 
norepinephrine easily penetrate the blood-bram barrier and stımulate the central adrenergic receptors of Hess ${ }^{11,12}$ Such phenylethylamines as amphetamine, dihydroxyphenylalanine (dopa) and lysergic acid diethylamide produce an EE G arousal pattern, enhanced psychomotor activity and an increased central sympathetic outflow ${ }^{13-17}$ Vasopressor drugs can also produce an arousal response in the intact animal during intravenous and inhalation anaesthesia ${ }^{18-19}$ In support of Brodie's position, the awakening effect of the phenylalanines (specifically $m$-tyrosine and dopa) following administration of reserpine has been said to be due to their eventual transformation to catecholamines ${ }^{0,21}$ As the stepwise transformation of tyrosine to dopa, dopamme, or tyramme and subsequently to noiepranephrine and epinephrine is well established (as shown in Fig 1) and since

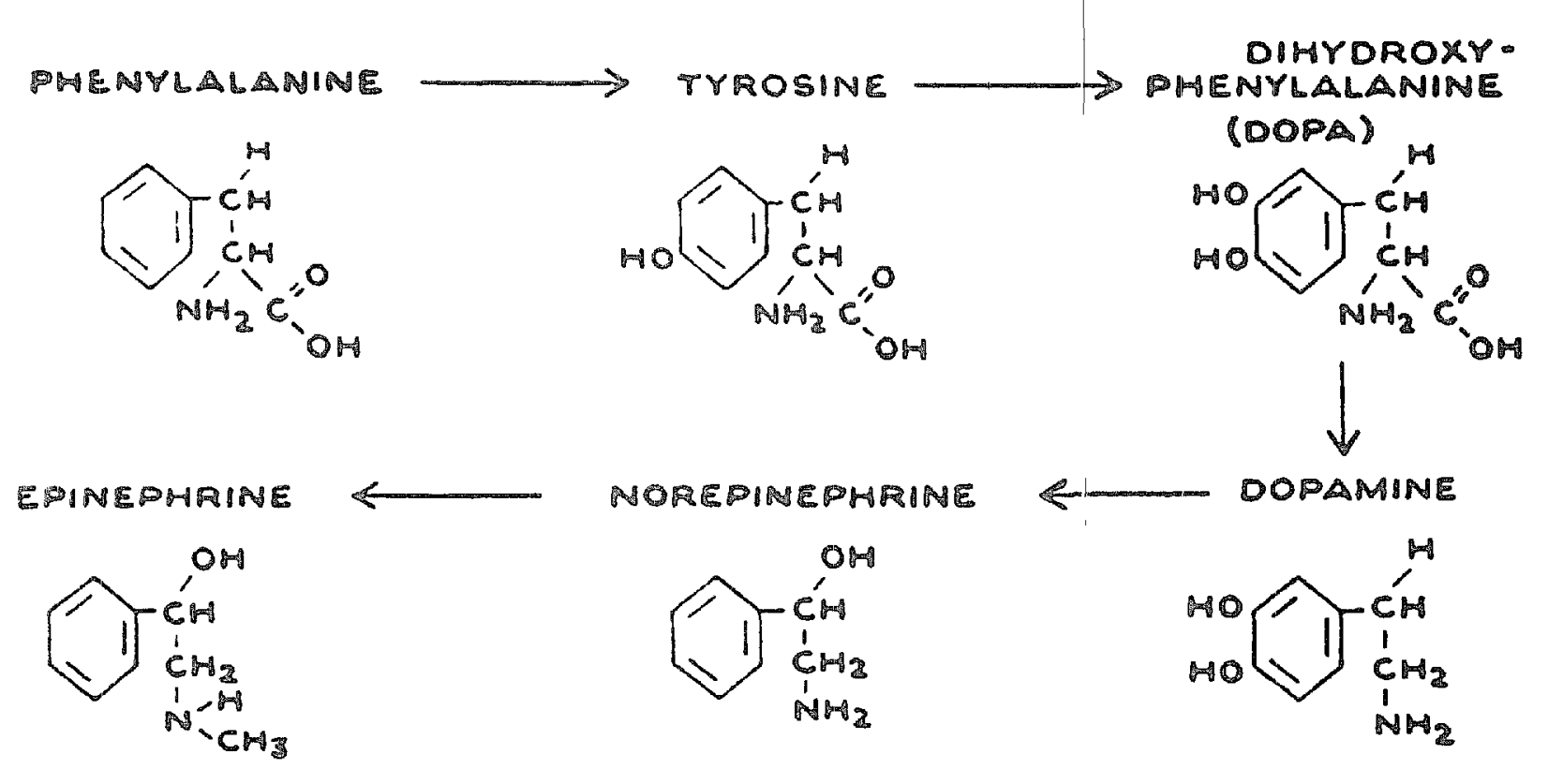

FIGURE 1 Some precursors of epinephrine

the cental stumulating effects of some catecholamines following intravenous injection are described, one may ask the further question "Do other precursors of epinephrine produce an arousal response that can be identified by clinical observation in the intact animal which has not been subjected to other drugs or contact stumulation?"

This study was undertaken therefore to evaluate the effect of the epinephrine precursors on spontaneous activity Tests were carried out with $l$-tyrosine, $d l$-mtyrosme, al-3,4-dihydroxyphenylalanine (dopa), 3,4-d hydroxyphenylethylamine (dopamine), levoarterenol (norepinephrine), and epinephrine

Tests were carned out with tyramine, methyldopate hydrochlonde (Aldomet ${ }^{\mathrm{R}}$ ester), and amphetamme sulphate, in addition, because they are closely related in chemical structure to the endogenous catecholamines Tyramine (4-hydroxyphenylethylamine) is a product of protem autolysis which occurs in the intestine of most animals It was used in this study because its pressor action is the same as that of norepinephrme, although its potency is only about 2 per cent by companson Methyldopate acts in the body as a decarboxylase inhibitor of dopa, thereby anterfering the formation of dopamine, and hence norepinephrine and epinephrine This is the apparent mechanism by which it may cause hypotension It also has a slight psychomotor effect (mood depression) which is quite 
distinct from the opposite effect of amphetamine-which has psychomotor actions which are similar to those of epinephrine Amphetamine is believed to act centrally by releasing endogenous catecholamines (dopamine) and it appears to prevent the uptake of circulating norepinephrine by the tissues ${ }^{22}{ }^{23}$ It differs from the sympathomimetic amines by having a nicotinic action, which may explain some of its central and peripheral stımulation and after-depression properties ${ }^{24}$

A simple device avalable in most laboratonies was used to permit quantitative measurements of activity and direct observation without use of electrical contacts or restraints on the rats The effect of some of these drugs on the hypnosis produced by methohexital anaesthesia was also measured by timing the rate of induction and duration of anaesthesia

\section{Materials and MEthods}

Experments were performed with 693 Sprague-Dawley male rats weighing 80 to 100 grams The rats were maintained in ipdividual cages with dry food and tap water avallable $a d l i b$
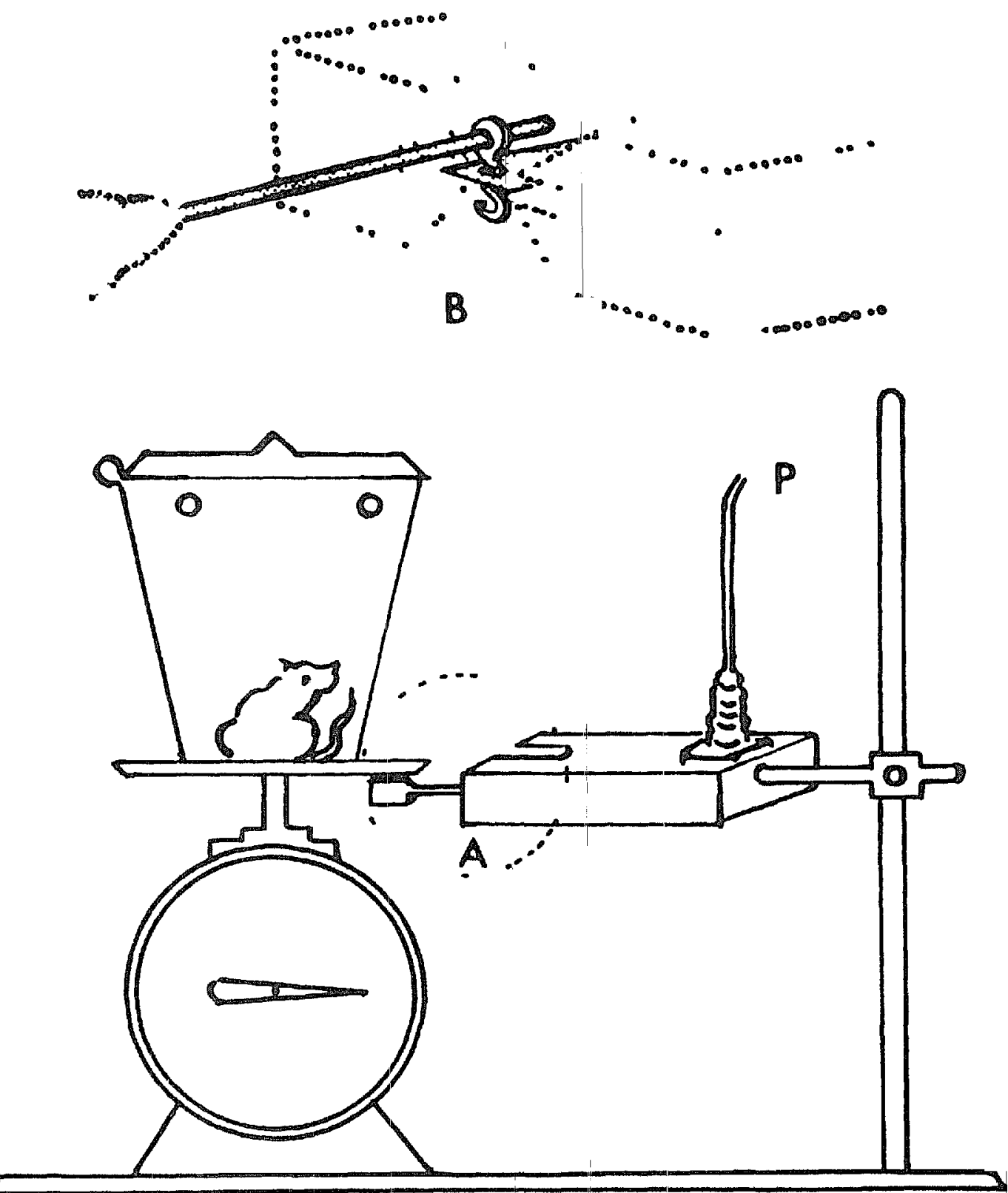

Figune 2 Apparatus for recording the overt actuvity of the rat ("jigglograph") 
The apparatus for recording activity is shown in Figure 2 Its basic arrangement consisted of a hypodermic needle attached beneath the receiving pan of a standard laboratory weighing scale and connected to a force displacement transducer B, which shows the detalls of the apparatus marked A This led to an amplifying and recording system (Grass polygraph, P in Figure 2) After placing a rat in a transparent rigid box (plexiglas) mounted on the receiving pan of the weighing device, sensitivity adjustment of the polygraph permitted even the smallest jiggling of the scale, such as would be caused by a panting movement, to be recorded

In order to quantitate the record, the number of deflections were measured on the recording paper and counted in the following four categories $5 \mathrm{~mm}$ (deflection length range, $4-9 \mathrm{~mm}), 10 \mathrm{~mm}$ (10-14 mm.), $15 \mathrm{~mm}$ (15-19 $\mathrm{mm}$ ), and $20 \mathrm{~mm}$ ( $20 \mathrm{~mm}$ or more), and the total amount of the deflections in centimetres was recoided as an activity score for the observation period

\section{Activity}

Individual one-hou recordings, which included an initial 20-minute control period and a 40-minute period after the drug injection;, were taken with 60 rats under the following 15 conditions (four rats per condition) (1) no drug, (2) $09 \%$ saline $(20 \mathrm{ml} / \mathrm{kg})$, (3) l-tyrosine $(200 \mathrm{mg} / \mathrm{kg})$, (4) l-tyrosine (600 $\mathrm{mg} / \mathrm{kg}$ ), (5) dl-m-tyrosine (200 $\mathrm{mg} / \mathrm{kg})$, (6) dl-m-tyrosine (600 mg $/ \mathrm{kg})$, (7) dopa (200 mg $/ \mathrm{kg}$ ), (8) dopa (600 $\mathrm{mg} / \mathrm{kg})$, (9) dopamine (200 mg $/ \mathrm{kg}$ ), (10) dopamine $(600 \mathrm{mg} / \mathrm{kg}),(11)$ methyldopate $(200 \mathrm{mg} / \mathrm{kg})$, (12) methyldopate $(600 \mathrm{mg} / \mathrm{kg})$, (13) tyramine $(200 \mathrm{mg} / \mathrm{kg})$, (14) tyramine (600 $\mathrm{mg} / \mathrm{kg}$ ), and (15) amphetamine (10 $\mathrm{mg} / \mathrm{kg}$ ) All drugs were given by intraperitoneal injection Two of each set of four rats wele later sacrificed and the peritoneum was examined to ensure that no urritation had occurred Recorded activity (in $\mathrm{cm}$ deflections) was tabulated for the 10 silccessive four-minute time intervals, starting 20 minutes after the drug injection

\section{Hypnosis}

To evaluate the effect of the drugs on the duration of anaesthesia, first 106 rats (control group) were injected intrapentoneally with methohexital (05\% solution, $30 \mathrm{mg} / \mathrm{kg}$ ) Induction time (the tume from imjection to loss of nighting reflex and loss of consciousness) and mantenance time (the time from the loss of consciousness unil the animal recovered enough to rase its head and walk) were recorded in minutes

An additional 527 rats were randomly divided into 12 groups (see Table I) There were eight test drug groups (33-35 rats per group) and four control groups (58-69 rats per group) The rats in all groups were anaesthetized with methohexital as in the control test group and anaesthesia unduction and mantenance tumes were recorded One week later, all groups were again anaesthetzzed with the same dose of methohexital The four control groups were injected with 0.9 per cent saline $(20 \mathrm{ml} / \mathrm{kg}$ ) simultaneously whereas the eight test groups each recenved one of four drugs by two methods as follows Method 1 intrapentoneal injection of the drugs 20 minutes pror to administration of methohexital to 
TABLE. I

Design of Experiment to Compare EfFect of Drugs on Hypnosis in Rats Produced by Methohexital (30 mg $/ \mathrm{kg}, 1 \mathrm{p}$ )

\begin{tabular}{|c|c|c|c|}
\hline \multirow[b]{2}{*}{ Drugs $(600 \mathrm{mg} / \mathrm{kg}, 1 \mathrm{p})$} & \multirow{2}{*}{$\begin{array}{c}\text { No. of } \\
\text { controls }\end{array}$} & \multicolumn{2}{|c|}{ Drug test groups } \\
\hline & & Method I* & Method II $\dagger$ \\
\hline $\begin{array}{l}\text { No drug } \\
m \text {-Tyrosine } \\
\text { Dopa } \\
\text { Methyldopate } \\
\text { Amphetamine }\end{array}$ & $\begin{array}{r}106 \\
58 \\
63 \\
66 \\
69\end{array}$ & $\begin{array}{l}\overline{35} \\
33 \\
33 \\
34\end{array}$ & $\begin{array}{l}\overline{35} \\
33 \\
33 \\
35\end{array}$ \\
\hline
\end{tabular}

* Method I - Test drug was injected 20 minutes pror to the adminıstration of methohexital

†Method II - Test drug was injected inmediately following the administration of methohexital

observe the duration of anaesthesia while the effect of the test drug motor activity was at its peak (four groups) Method 2 intraperitoneal injection of drugs immeduately following that of methohexital, to see whether the response was different (four groups) For each rat, anaesthesia induction and maintenance tımes were recorded in minutes as described above $m$-Tyrosine, dopa, and methyldopate were given in a dose of $600 \mathrm{mg} / \mathrm{kg}$, whereas $10 \mathrm{mg} / / \mathrm{kg}$ amphetamine was given

\section{Results}

\section{Activity}

When each rat was placed in the transparent chamber, a considerable amount of exploratory activity was noted at first, then the activity subsided and the rat usually appeared to be asleep Part A of Figure 3 shows the tracings representing exploratory activity and periods of quiescence as recorded on the "jigglograph" Part B of Figure 3 shows the typical recolds of the activity following injection of various catecholamine precursors and the non-physiological chemicals $m$-tyrosine, methyldopate, and amphetamine at the tume when maximum actıvity was observed This maximum activity was invariably observed durng the 20 to 60 minutes following the drug injections The latent period of about 20 minutes pror to the manifestation of drug action probably represents the time required to produce a motor response directly or to convert these drugs in the body to some physiologically active form

Figure 4 shows the graphic representation of the activity counts per 4-minute tume interval over the 40 -minute period starting from 20 minutes following the injections of the various drugs Each line shows the typical response for one representative experiment with the designated drug Table II shows the detalled results obtaned with four individual rats for each of the drugs given in doses of $200 \mathrm{mg}$ and $600 \mathrm{mg}$ per $\mathrm{kg}$ of body weight

It may be seen in Figure 4 and Table II that the rats injected with the nonphysiological compound $m$-tyrosine ( 200 and $600 \mathrm{mg} / \mathrm{kg}$ ) were somewhat more active than those given the natural $l$-tyrosine While $200 \mathrm{mg} / \mathrm{kg}$ of dopa had 


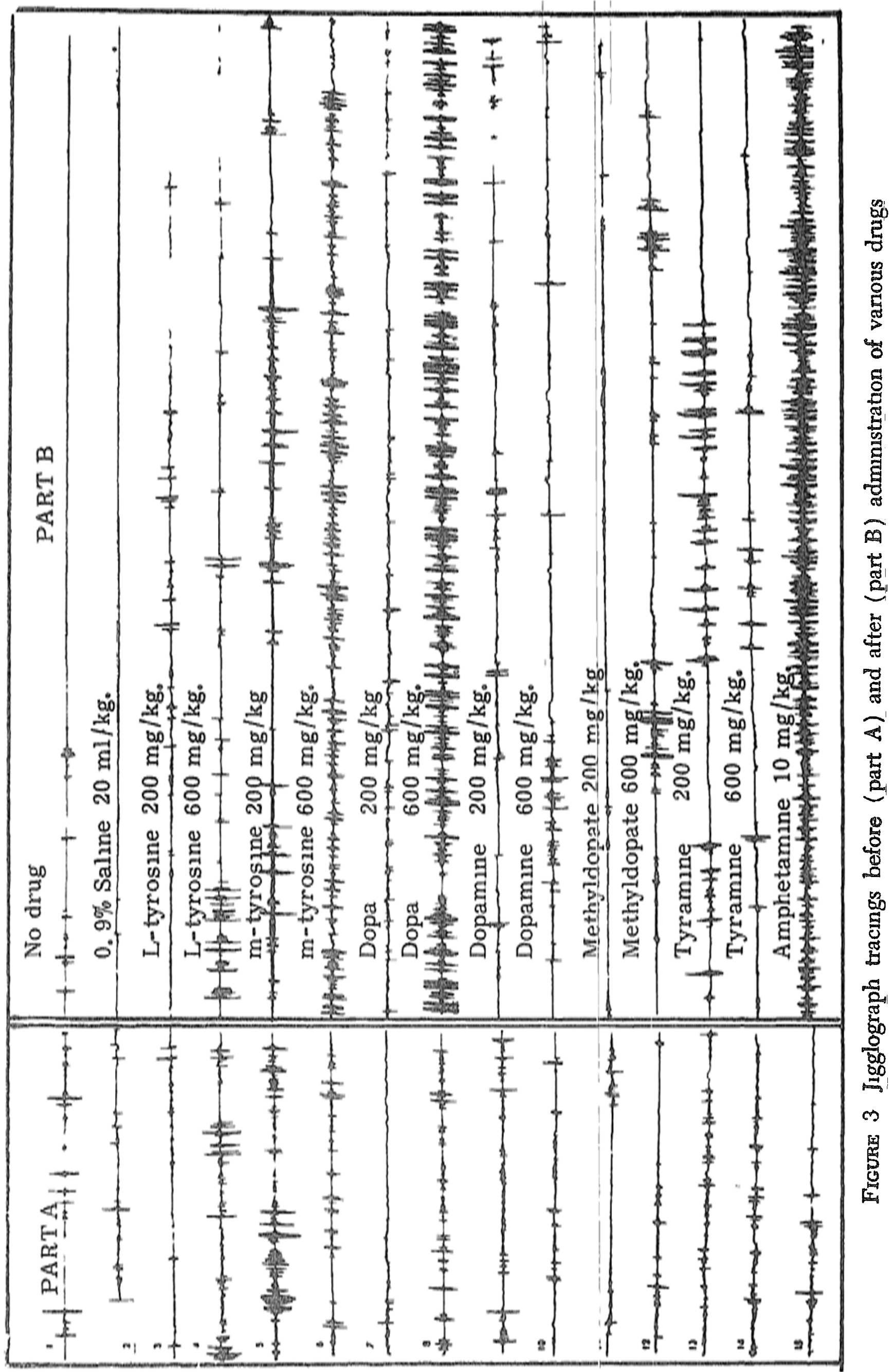


Rat Activity Counts from Jigglograph Recording in $\mathrm{cm}$ from 20 to 60 min aftel Injection of Drugs

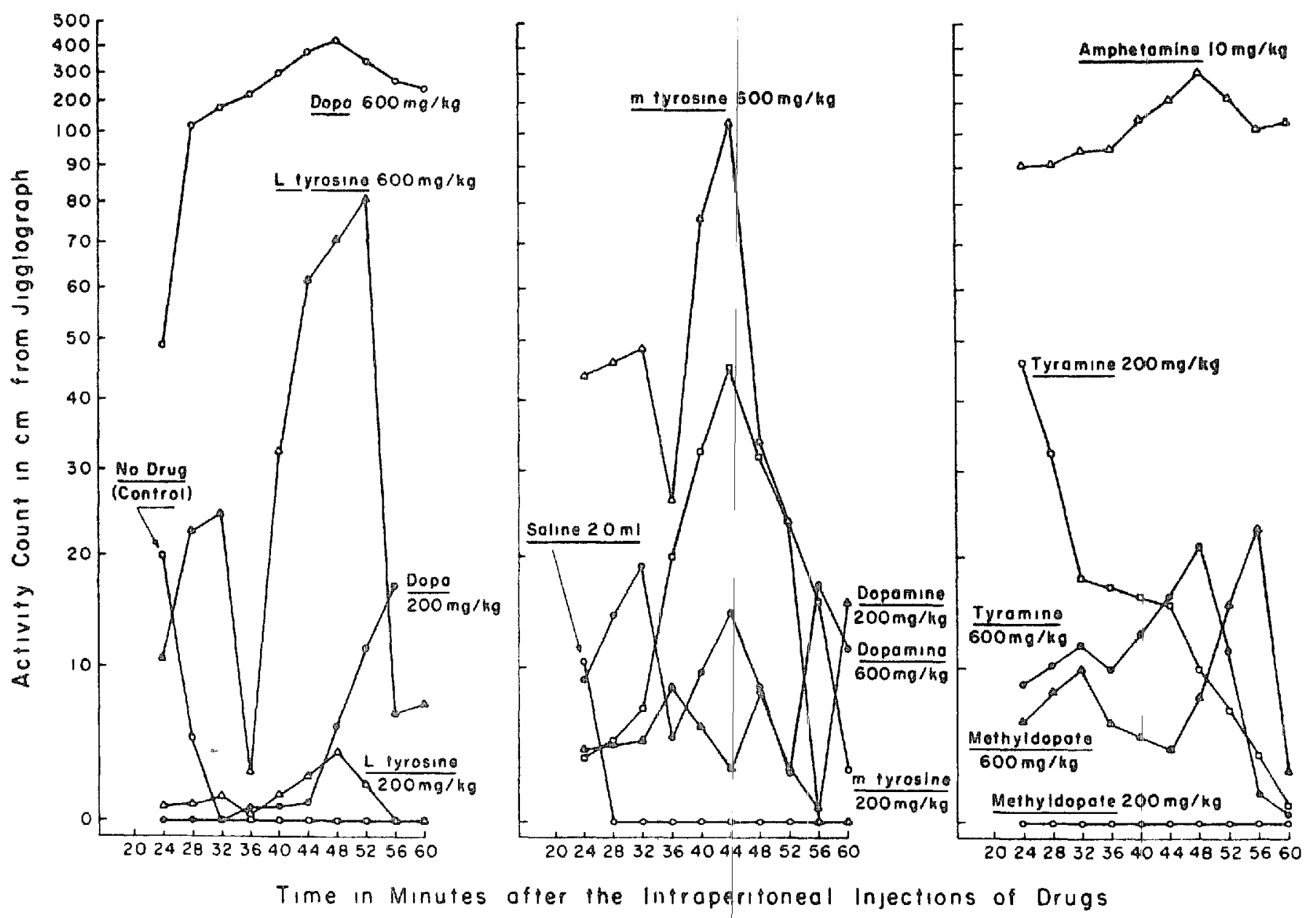

Figure 4 Rat activity counts from jigglograph rerording in $\mathrm{cm}$ from 20 to 60 minutes after injection of drugs

TABLE III

Rat Activity Counts Produccd by the Intraperitoneal Injection of Varlous Drugs

\begin{tabular}{|c|c|c|c|c|c|c|c|c|}
\hline \multirow{2}{*}{\multicolumn{2}{|c|}{ Drugs }} & & \multicolumn{4}{|c|}{ Rats } & \multirow[b]{2}{*}{ Mean } & \multirow{2}{*}{$\begin{array}{l}\text { Standard } \\
\text { deviation }\end{array}$} \\
\hline & & & 1 & 2 & 3 & 4 & & \\
\hline $\mathbb{1}$ & No drug & & 256 & 156 & 105 & 20 & 181 & 65 \\
\hline 2 & $09 \%$ saline & $20 \mathrm{ml} / \mathrm{kg}$ & 105 & 215 & 59 & 10 & 120 & 66 \\
\hline & $\begin{array}{l}l \text {-Tyrosine } \\
l \text {-Tyrosine }\end{array}$ & $\begin{array}{l}200 \mathrm{mg} / \mathrm{kg} \\
600 \mathrm{mg} / \mathrm{kg}\end{array}$ & $\begin{array}{r}244 \\
3700\end{array}$ & $\begin{array}{r}34,9 \\
397,5\end{array}$ & $\begin{array}{r}357 \\
4401\end{array}$ & $\begin{array}{r}19 \\
357\end{array}$ & $\begin{array}{r}287 \\
3913\end{array}$ & $\begin{array}{rl}7 & 8 \\
36 & 6\end{array}$ \\
\hline & $\begin{array}{l}m \text {-Tyrosine } \\
m \text {-Tyrosine }\end{array}$ & $\begin{array}{l}200 \mathrm{mg} / \mathrm{kg} \\
600 \mathrm{mg} / \mathrm{kg}\end{array}$ & $\begin{array}{l}1970 \\
4580\end{array}$ & $\begin{array}{l}207,7 \\
478,8\end{array}$ & $\begin{array}{ll}257 & 3 \\
547 & 9\end{array}$ & $\begin{array}{l}178 \\
393\end{array}$ & $\begin{array}{l}2102 \\
4697\end{array}$ & $\begin{array}{ll}33 & 5 \\
63 & 5\end{array}$ \\
\hline $\begin{array}{l}7 \\
8\end{array}$ & $\begin{array}{l}\text { Dopa } \\
\text { Dopa }\end{array}$ & $\begin{array}{l}200 \mathrm{mg} / \mathrm{kg} \\
600 \mathrm{mg} / \mathrm{kg}\end{array}$ & $\begin{array}{r}400 \\
26150\end{array}$ & $\begin{array}{r}56 \\
3156.6\end{array}$ & $\begin{array}{r}369 \\
23154\end{array}$ & $\begin{array}{r}46 \\
2173\end{array}$ & $\begin{array}{rl}45 & 0 \\
2565 & 0\end{array}$ & $\begin{array}{r}87 \\
4352\end{array}$ \\
\hline $\begin{array}{r}9 \\
10\end{array}$ & $\begin{array}{l}\text { Dopamine } \\
\text { Dopamine }\end{array}$ & $\begin{array}{l}200 \mathrm{mg} / \mathrm{kg} \\
600 \mathrm{mg} / \mathrm{kg}\end{array}$ & $\begin{array}{r}790 \\
1225\end{array}$ & $\begin{array}{r}95.8 \\
1775\end{array}$ & $\begin{array}{ll}59 & 4 \\
98 & 3\end{array}$ & $\begin{array}{r}63 \\
201\end{array}$ & $\begin{array}{rl}745 \\
150 & 0\end{array}$ & $\begin{array}{ll}16 & 4 \\
47 & 8\end{array}$ \\
\hline $\begin{array}{l}11 \\
12\end{array}$ & $\begin{array}{l}\text { Methyl dopate } \\
\text { Methyl dopate }\end{array}$ & $\begin{array}{l}200 \mathrm{mg} / \mathrm{kg} \\
600 \mathrm{mg} / \mathrm{kg}\end{array}$ & $\begin{array}{r}0 \\
1035\end{array}$ & 1153 & $\begin{array}{c}0 \\
905\end{array}$ & $\begin{array}{r}0 \\
165\end{array}$ & $\begin{array}{r}0 \\
1187\end{array}$ & $\begin{array}{c}0 \\
327\end{array}$ \\
\hline $\begin{array}{l}13 \\
14\end{array}$ & $\begin{array}{l}\text { Tyramine } \\
\text { Tyramine }\end{array}$ & $\begin{array}{l}200 \mathrm{mg} / \mathrm{kg} \\
600 \mathrm{mg} / \mathrm{kg}\end{array}$ & $\begin{array}{ll}181 & 7 \\
115 & 0\end{array}$ & $\begin{array}{l}1287 \\
1287\end{array}$ & $\begin{array}{l}1782 \\
1983\end{array}$ & $\begin{array}{l}220 \\
202\end{array}$ & $\begin{array}{ll}177 & 2 \\
161 & 0\end{array}$ & $\begin{array}{l}376 \\
457\end{array}$ \\
\hline 15 & Amphetamine & $10 \mathrm{mg} / \mathrm{kg}$ & 23176 & 29869 & 20147 & 2437 & 24392 & 4056 \\
\hline
\end{tabular}


little effect, $600 \mathrm{mg} / \mathrm{kg}$ produced some of the highest activity levels recorded among the drugs tested Dopamine had some effect at $200 \mathrm{mg} / \mathrm{kg}$, but very little compared to that of dopa at $600 \mathrm{mg} / \mathrm{kg}$ Methyldopate appeared to cause total depression at the $200 \mathrm{mg} / \mathrm{kg}$ dose, but produced a little stımulation with the $600 \mathrm{mg} / \mathrm{kg}$ dose The effect of tyramine was simular to that of dopamine but neither drug caused an increase in activity with an increase in dosage The effect of amphetamine $(10 \mathrm{mg} / \mathrm{kg}$ ) was similar to that of $600 \mathrm{mg} / \mathrm{kg}$ dopa Injection of a tolerable single maximum dose of epinephrine and nor epinephrine $(2 \mathrm{mg} /$ $\mathrm{kg})$ produced very limited activity changes, the transient effect being due to their evanescent action

Although activity counts increased following the injections of tyrosine, tyramine, and dopamine, in comparison with the control tests with and without saline, these drugs seemed to produce a peculiar sedative state characterized by partially or completely closed eyes, immobility, and the general appearance of sleep Numerous aperiodic startle responses were observed in these virtually dormant animals, which accounts for the augmented activity values derived from the recording

Rats given $10 \mathrm{mg} / \mathrm{kg}$ amphetamine or $600 \mathrm{mg} / \mathrm{kg}$ of dopa did not react in this manner Instead, they shoued a continuous state of agitation With 200 $\mathrm{mg} / \mathrm{kg}$ dopa, the rats showed only a transient increase in recorded activity, but no sedative effect was apparent

Durect visual observations of the rats indicated rather obvious differences in the response to dopa compared with that to amphetamine Dopa seemed to produce purposeful and co-ordinated motor movements whereas, in addition to co-ordinated motion, amphetamine produced a constant tremor-like movement of the extremities and facial musculature

\section{Hyprosis}

Mean induction and mantenance times in minutes, under the control and the two-test procedure conditions, and the probability values obtaned with the Fisher " $i$ " test are shown in Table III Mean induction times ( 10 to 16 minutes) and mantenance times ( 13 to 20 minutes) of the rats anaesthetized with methohexital without saline (106 rats) and with saline (527 rats) were similar It was assumed therefore that the control tests piovided a valid base-line with which to compare the response to the combinations of methohexital with $m$-tyrosine, dopa, methyldopate, and amphetamine

Induction times were longer with all the test drugs except amphetamine in the first method, while in the second method (simultaneous injection of hypnotics and precursors), $m$-tyrosine and dopa appreciably prolonged the induction torne It may be seen also that with the first method the mantenance tume was signuficantly prolonged with $m$-tyrosine, dopa, and methyldopate, whereas amphetamine did not prolong the maintenance time Similarly, when the precursors were given at the same time as the anaesthetic, maintenance tumes were prolonged in comparison with the controls, with the exception of amphetamine, which tended to shorten anaesthesia tume 
TABLE III

Summary of Data Showing Effect of Drugs on Duration of Methohcxital Anaesthesia

\begin{tabular}{|c|c|c|c|c|c|}
\hline \multirow{3}{*}{ 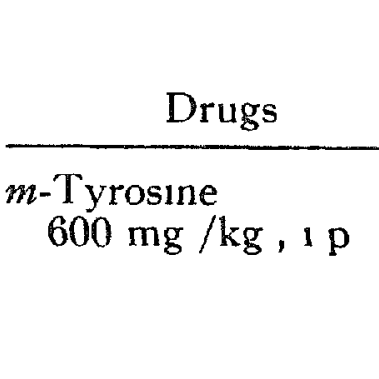 } & \multicolumn{2}{|c|}{$\begin{array}{l}\text { Time of } \\
\text { injection* }\end{array}$} & $\begin{array}{c}\text { Control gioups, } \\
\text { mean time } \\
\text { (muntes) }\end{array}$ & \multirow{2}{*}{$\begin{array}{c}\begin{array}{c}\text { Experimental groups, } \\
\text { mean time } \\
\text { (minutes) }\end{array} \\
19 \pm 076 \\
252 \pm 100\end{array}$} & \multirow{2}{*}{$\begin{array}{c}\begin{array}{c}\text { Significance } \\
(p \text { values })\end{array} \\
\begin{array}{c}>0001 \\
002-0001\end{array}\end{array}$} \\
\hline & I & $\underset{\text { MTt }}{\operatorname{IT} \dagger}$ & \begin{tabular}{rl|ll}
1 & 0 & \pm 0 & 37 \\
13 & 8 & \pm & 3
\end{tabular} & & \\
\hline & II & $\stackrel{\text { IT }}{\mathrm{MT}}$ & \begin{tabular}{rl|ll}
1 & 1 & \pm 0 & 33 \\
13 & 6 & \pm 4 & 6
\end{tabular} & $\begin{array}{rl}16 \pm 0 & 62 \\
19 & 4 \pm 7 \\
\end{array}$ & $\begin{array}{l}>0001 \\
\mathrm{~N} \mathrm{~S}\end{array}$ \\
\hline \multirow[t]{2}{*}{$\begin{array}{l}\text { Dopa } \\
\quad 600 \mathrm{mg} / \mathrm{kg}, \mathrm{lp}\end{array}$} & I & $\stackrel{\text { IT }}{\mathrm{MT}}$ & $\begin{array}{rl}12 & 2 \pm 013 \\
174 \pm 65\end{array}$ & $\begin{array}{rl}29 & 9 \pm 15 \\
357 \pm 150\end{array}$ & 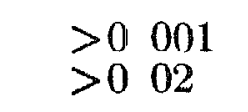 \\
\hline & II & $\stackrel{\operatorname{IT}}{\mathrm{MT}}$ & $\begin{array}{rlll}1 & 3 & \pm 0 & 28 \\
15 & 1 & \pm 3 & 1\end{array}$ & $\begin{aligned} 21 & \pm 072 \\
248 \pm 93 & \pm 93\end{aligned}$ & $\begin{array}{l}>0001 \\
>0\end{array}$ \\
\hline \multirow[t]{2}{*}{$\begin{array}{l}\text { Methyldopate } \\
600 \mathrm{mg} / \mathrm{kg}, 1 \mathrm{p}\end{array}$} & $\mathbb{I}$ & $\stackrel{\mathrm{IT}}{\mathrm{MT}}$ & $\begin{array}{rl}1 & 4 \pm 040 \\
17 & 3\end{array} 47$ & 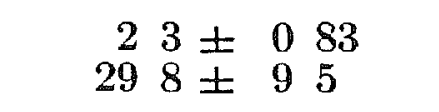 & $\begin{array}{ll}>0 & 001 \\
>0 & 02\end{array}$ \\
\hline & II & $\stackrel{\mathrm{IT}}{\mathrm{MT}}$ & 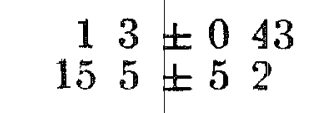 & $\begin{array}{ll}14 & 438 \\
201 \pm 62 & 1 \pm 0\end{array}$ & $\begin{array}{c}\text { N S } \\
0 \quad 02-0 \quad 05\end{array}$ \\
\hline Amphetamine & I & $\mathrm{IT}$ & $16 \pm 040$ & $13 \pm 035$ & 005 \\
\hline $10 \mathrm{mg} / \mathrm{kg}, 1 \mathrm{p}$ & II & $\begin{array}{l}\mathrm{MT} \\
\mathrm{IT}\end{array}$ & $\begin{array}{rlll}19 & 2 \pm 6 & 6 \\
1 & 3 & \pm & 24 \\
19 & 8 \pm 6 & 9\end{array}$ & $\begin{array}{rl}20 & 9 \pm 6 \\
16 \pm 0 & 6 \\
17 & 8 \pm 6 \\
17 & 0\end{array}$ & $\begin{array}{l}\mathrm{NS} \\
005 \\
\mathrm{NS}\end{array}$ \\
\hline
\end{tabular}

\section{Discussion}

One of the major stumbling blocks that the clinician faces in the evaluation of overt reactions to drugs can be attributed to the lack of reliable objective criteria for defining inhibitory (or depressive) and excitatory (or awakening) responses Any particular observed overt response can be accounted for by invoking an excess of inhibition or a deficit of excitation and a decrement of inhibition on an excess of excitation It becomes a complex task to sort out the relative contribution and the degree of independence of these two processes In broad psychological terms, depression or inhibition may refer to a process in the central nervous system which interferes with the ongoing perceptual, cognitive, and motor activities of the organism The types of interference have been called temporal and spatial inhibition Temporal inhibition is a fatigue-like state which interferes with performance and usually dissipates during rest For instance, whenever a long-continued and monotonous visual or auditory activity is carried out, performance is adequate at first, but vigilance declines after awhile, and ceases finally on account of temporal inhibition. Spatial inhibition, on the other hand, is a process in which some form of sensory deprivation occurs, or the stumulus becomes imperceptible because another sensation has been evoked by simultaneous stumulation elsewhere in the sensory field

In the same terms of reference, excitahon or arousal refers to a process within the central nervous system which facilitates the ongoing perceptual, cognitive, 
and motor activities of the organism Sensory thresholds may be influenced by the organism's degree of central nervous system excitation in addition to peripheral nervous factors and external noxious stimuli ${ }^{25}$

When an animal is situated in a quiet environment and is virtually free of all extrinsic sensory impulses, its electroencephalogram discloses alterations from a more or less alert state to one of sleepiness An alert pattern is readily evoked by any peripheral external sensory stimulus, and the $\mathbb{E} E G$ shows widespread alert activity over the cortex, especially when the animal is touched or a panful stimulus is applied Himwich has posed the question Does epinephrine cause arousal in such an animal by direct action on the reticular formation, or is the effect the result of stimuli originating from peripheral receptors that are activated by epinephrine as occurs when the animal is touched ${ }^{p 1}$. The work reported by the French workers cited above ${ }^{\vartheta}$ indicates that epinephrine exerts a durect alerting effect upon the reticular formation and that the inirmsic mechanism is adrenergic in character They showed that the alerting effect of epinephrme is not due to its vasopressor action because there were discrepancies in the time course of the blood pressure changes and EE G alerting These observations have been clearly confirmed by others ${ }^{26,27}$ However, we have dinectly observed overt alerting responses in dogs immediately following the injection of various vasopressors during moderately deep anaesthesia, ${ }^{18}{ }^{19}$ so it seems that in the intact organism epinephrine and related vasoactive substances stimulate a wide range of receptors and the final psychic effect is the result of numerous cardiovascular, respiratory, and cortical effects, including stimulation of baroreceptors (which might cause inhibition of the reticular formation), but at the same time, or preceding this, local cerebrovascular changes occur which can alter cerebral blood flow and cause an overriding stimulation of the reticular formation ${ }^{1028}$ Thus, the arousing effect of epinephrine can be attributed to changes in cerebral blood flow even if appreciable or immediate hypertension does not occur Capon has shown that epinephrine antagonists inhibit central activation to the same extent that they prevent the cardiovascular effects of epinephrme, and has observed, as we have, that other vasopressors can cause arousal ${ }^{29}$ In a review of the effect of various drugs on the cerebral curculation, Sokoloff cites work which showed that the intravenous administration of epinephrine and amphetamine has little or no effect on cerebral blood flow, whereas norepinephrine and sevesal of the vasopressor sympathomimetic drugs do produce an appreciable quantitative increase in the cerebral blood flow-which may reflect only a passive response of the cerebral crrculation to a rise in systemic blood pressure and/or the effects of an increased cerebral metabolic rate ${ }^{30}$

It is evident that the constant stream of sensory and proproceptive stimul, to which an awake animal is exposed all day, sets up inhibitions of the stimulusproduced kind which have no time to dissipate unless it is placed in a confined area where external stimulation is eliminated One can also imagine a constitutional property of the central nervous system such that an animal is constantly in a state of greater or lesser excitation or inhibition while awake Drugs which affect the sensornum, the cardiovascular system, and the respiratory system can undoubtedly alter this sensory state From a physiologiral point of view, we know 
that changes in the excitatory or arousal state of the central nervous system and the reticular system can be monitored by continuously recording the electrical activity in the brain ( $E \mathbb{E} G$ ), neuromuscular action potentials ( $E M G$ ), and galvanic skın resistance ( $G S R$ ) It appears obvious, therefore, that any alteration in spontaneous activity must be due to widespread effects rather than one confined to the brain We chose the use of the apparatus described in this report in order to eliminate all forms of contact which might modify the response of the rats to the drugs tested

The important lesson we learned from this study was the fact that mechanical recording of spontaneous activity doe" not alone reveal the entire overt behavioural responses of the intact experimental animal, so it is of the utmost importance to observe the animal directly visually and to annotate the responses before, and while it is under the influence of drugs, if one desires reliable $\mathrm{m}$ formation as to overt responses

Previous work that has indıcated an alertung effect by derivatives of phenylalanine (tyrosine, dopa, dopamine, and noradrenaline) 2021,313233 for the most part was done in animals that were tranquillized by large doses of reserpine or prepared with monamine oxidase inhibitors Carlsson and associates found that dopa is capable of penetraing into the brain via the blood It is then rapidly decarboxylated to form dopamine, and the dopamine thus formed is concentrated in those parts of the brain where either dopamine or norepinephrine is present normally ${ }^{31}$ They found that if the catecholamine level in the brain was increased by the injection of dopa, central excitation was observed The exciting effect was greater If the animal was previously depressed by monamine oxidase The loss of alertness and motor activity following reserpinization was restored also by administration of dopa These observations seem to support the view that catecholamines in the brain are involved in the control of psychomotor activity

The rather striking dufference between the effects of amphetamine and dopa on spontaneous activity that we observed directly and the visual observation of startle movements durnng a sleep-like ttate following adminıstration of tyrosine 1aises doubts as to the validity of the idea that lipid-soluble congeners of epinephrine easly penetrate the blood-brain barrier and cause the same knd of stimulation in the central adrenergic receptors of Hess's ergotrophic division ${ }^{11} 12$ If these phenylethylamines produce an increase in sympathetıc activity by a mechanism similar to that produced by norepinephrine and epinephrine-as might be expected because therr chemical structures are closely related-their lipid solubilities are comparable, and because they can undergo a stepwise transformation towards catecholamines, then they should produce a more obvious and an essentially similar activity also The "jigglograph" recordings, together with our durect observation that there was a lack of dose-response relationships following adminıstration of dopamine, tyramine, and related drugs, did not indicate to us that there was any such effect

The effect of the short-acting hypnotic (methohexital) combined with the catecholamine precursors also did not support the "similar mechanism" position, cited above, because administration of these catecholamine precursors (except amphetamine) definitely prolonged maintenance time of anaesthesia The effect 
on induction time by amphetamme with Method 1 (but not with Method 2) seems to indicate that this drug produces some physiological or psychological effect on the awake rat which causes a shortening of induction time when it is injected prior to methohexital This may be attributed to physical exhaustion due to drug-induced excitement which would not occur when the amphetamine is injected at the same time as the anaesthetic If these phenylethylammes all act upon the same receptor site for sympathetic stimulation and in the same manner, then these drugs should have shortened the hypnotic effect of methohexital, as amphetamine may do, instead of uniformly prolonging it Since amphetamine was the only agent tested that did not prolong the mantenance time of anaesthesia, it does not seem reasonable to classify other catecholamine precursors (such as dopa) with amphetamine as a sympathetic stimulating agent which can increase psychomotor activity Indeed, the effect of the precursors we studied on the central nervous system seemed quite different

Anothe1 worker has shown that there is a decrease of reflex activity of rats with dopamine whereas amphetamine increases it ${ }^{34}$ Smith and Dews also reported that dopa markedly suppressed the locomotor activity of normal rats ${ }^{35}$ Randrup and associates reported that amphetamine failed to be antagonized by adrenergic blocking dgents and, therefore, is not an adrenergic drug ${ }^{36}$ These results seem to support our observations, which indicate that the effects of amphetamine and the phenylalanine derivatives cannot be considered in the sume category

A possible explanation for the observed prolongation of hypnosis with metho hevital by some of the catecholamine precursors can be drawn from the study by Conney and associates, who demonstrated their depressant action on enzymes in the liver microsomes which metabolize barbiturate compounds ${ }^{37}$ We can there' fore assume that the catecholamme precursors may upset the metabolism of methohexital in the liver enough to prolong its anaesthetic effect The catechola, mine precursors may also prolong hypnosis by reducing the rate of elimination of barbiturates through the kidneys Welles and associates reported that 80 per cent of methohexital given to rats was excreted in faeces whlle 20 per cent was excreted in urine, ${ }^{38}$ which indicates that both of the ablove assumptions may be valid One can surmise also that epinephrine precursors might prolong the effect of barbiturate anaesthesia through a direct depressant effect on the brain itself

\section{SUMmary AND CONCLUSIONS}

Adrenergic arousal reactions have been shown to occur by behavioural responses as well as by changes in the electroencephalogram due to stimulation of the ascending sensory receptors in the reticular activating system There is good evidence that the arousal response is not due to the vasopressor action of epinephrine, although clinical observations with most vasopressor drugs point to such an explanation Local vascular changes in the brain which are not necessarily reflected in the general crrculation have been suggested and demonstrated as a likely explanation for psychomotor activation by epinephrine

The precursors of epinephrine also seem to play a role in the control of alertness and motor functions The negative aspect of this idea explains in part the decrease 
in spontaneous activity and depression of psychomotor activity in $\mid$ response to reserpine administration The question of whether or not phenylalanine derivatives can themselves produce awakening reactions has been studied to a lumited extent A very large dose of $l$-dopa does produce an awakening response in reserpinized mice To a less extent, $m$-tyrosine appears to have a similar effect The two ssomers of dopa and o-tyrosine, however, are devold of the activating property, Other epınephrine precursors, except norepinephrine, are virtually mert

This study was devised to determine whether the epmephrine precursors (phenylalanme derivatives) as well as tyramine, methyldopate, and amphetamme produce an alerting response and increased motor activity in rats deprived of extrinsic stımulation Before and following intraperitoneal injection of the test drugs, rats were placed individually in a transparent box that was mounted on a weighing scale and attached to a recording apparatus which inscribed on paper even the slightest movement of the rat All of the catecholamine precursors studied produced some alterations in the spontaneous activity of the rats $d l$-Dopa caused the greatest increase in motor activity, the reaction being quantitatively similar to that seen with amphetamine $l$-Tyrosine, $m$-tyrosine, tyramme, and dopamine produced a peculiar effect on the rats-they appeared as if they were under the influence of a potent sedative, but they had numerous aperiodic startle movements which, on the recording, appeared as if they had a substantial alerting reaction Although the activity tracing for amphetamine and dopa appeared similar, the rats appeared quite different on direct observation Dopa produced an increase in motor activity which appeared co-ordinated and purposeful, whereas amphetamine caused an increase in co-ordmated movements but there was also a generalized increase in body movement that resembled muscle trembling, similar to that seen in nicotine poisoning

The effect of $m$-tyrosine, dopa, methyldopate, and amphetamine given 20 minutes before or simultaneously with methohexital anaesthesia revealed, contrary to expectation, that hypnosis was uniformly prolonged with each, except with amphetamine These data were interpreted as contradicting the opinion that the psychomotor effects of the catecholamine precursors can be considered in the same category as epmephrme It was also evident that amphetamine acts quite differently from the precursors of epinephrine, whereas methyldopate either suppresses motor activity or has very little activity in this regard

\section{RÉSUMÉ}

Des réactıons adrénergıques de réveıl se sont manıfestées aussı bıen par lè réponses des sujets que par les modifications sur le tracé électroencephalographique à la suite de la stımulation des récepteurs sensoriels ascendants dans le système rétıculé actıvateur Il exıste une évidence assez forte que la réponse d'éveil n'est pas due à l'action vasopressive de l'épinephrine bien que des observatıons clinıques en employant la plupart des médicaments vasopresseurs portent à croire cette explication On a suggéré et on a démontré, comme une explıcation vraisemblable de l'actıvation psychomotrice par l'épınephrine, des changements qui n'ont pas nécessarrement d'écho sur la grande circulation

Même les précurseurs de l'épınéphrine semblent jouer un rôle dans la contrôle 
des fonctions de velle et de motricité L'aspect négatif de cette idée explique en partie la diminution de l'activité spontanée et la dépression de l'activité psychomotrice en réponse au traitement par la réserpine Jusqu’à un certain point, nous avons essayé de déterminer si oui ou non les dérivés de la phénylalanine pouvalent eux-mêmes provoquer des réactions de révell Une dose très forte de l-dopa est capable de provoquer une réponse de révell chez la sourns trartée à la réserpine De façon moins marquée, la $m$-tyrosine semble provoquer une réponse semblable Les deux ssomères de dopa et $o$-tyrosine, toul efors, sont dépourvus de toute propriété d'activation Les autres précurseurs de l'épınephrine, à l'exception de la norépinéphrine, sont virtuellement mortes

Nous avons entrepris cette étude dans le but de préciser sil les précurseurs de l'épınéphrme (les dérivés de la phénylalanıne) et la tyramme, le dopate de méthyle et l'amphétamine peuvent provoquer des réponses de réveil et une actıvité motrice accrue chez des rats dépourvus de stımulation extérieure

Avant et après l'injectıon intrapéritonéale à des rats des médicaments étudiés, nous avons placés ces anımaux séparement, chacun dans une boîte transparente, montée sur une balance et attachée à une appareil enregistreur qui inscrit sur un papier le plus léger mouvement du rat Tous les précurseurs de catécholamine étudiés ont produit certanes modlifications de l'activité spontanée des rats La dopa a produit la plus grande augmentation de l'actıvité motrice, mais, quantitatıvement, la réaction a été semblable à celle observée avec l'amphétamine $l$-Tyrosine, $m$-tyrosine, la tyromine et la dopamine ont produit, sur les rats, un effet particulier, ils semblaient devenur sous l'effet d'un puissant sédatıf, mais ils faisaient de nombreux mouvements à intervalle urrégulier, sur le tracé, comme s'ils avarent une forte réaction d'éveil

Bien que les tracés de l'actıvité pour l'amphetamine et la dopa soient semblables, à l'observation directe, les rats semblaient tout dufférents La dopa a produit une augmentation de l'actıvité motrice qui a semblé coordonnée et intentionnée, tandis que l'amphétamine a produt une augmentation des mouvements coordonnés, mais il est apparu également une augmentation totale des mouvements du corps qui ressemblait à un tremblement muscularre, comparable à ce que nous observons au cours de l'empoisonnement par la nicotme L'effet de l'm-tyrosine, de la dopa, du dopate de méthyle et de l'amphétamine donnés 20 minutes avant ou en même temps qu'une anesthésie au méthohexital a montré que, contraurement à ce que nous étions en droit d'attendre, avec chacun de ces médicaments, le sommeil a été uniformément prolongé à l'exception de l'amphétamine

Ces résultats sont interprétés comme contredisant l'opinıon voulant que les effets psychomoteurs des précurseurs des catécholamines soient considérés de la même catégorie que ceux de l'épinéphrine Il était également manifeste que l'amphétamine, agit tout a fait différemment des précurseurs de l'épınéphrine alors que le dopate de méthyle peut, soit supprimei l'activité motrice soit n'agur que très peu dans ce sens

\section{ACKNOWLEDGMENT}

Methyldopate hydrochloride was kindly supphed by Merck Sharp and Dohme Company 


\section{REFERENCES}

1 von Euler, US Noradrenaline Chemistry, Physıology, Pharmacology and Clinical Aspects Springfield, IIl C C Thomas (1956)

2 Brewster, W R, Isaacs, J P, \& Anderscin, T W Depressant Effect of Ether on the Myocardium of the Dog and Its Modificalion by Reflex Release of IFpinephrine and Norepinephrme Am J Physiol 175399 (1953)

3 Price, H L, Linde, H L, Brack, G W, \& Price, M L Sympatho-atdrenal Response to General Anesthesia ind Relationship to Hemodynamics Anesthesiology 20563 (1959)

4 Hoffer, A , Osmond, H, \& Smythies, J R Schizophrenia A New Appłoach II Results of a Year's Research J Mental Sc1 10029 (1954)

5 Rinkel, M \& Solomon, H C Chemical theones of Psychosis J Clin Exptl Psychopathol 13323 (1957)

6 Szara, S, Axezrod, J, \& Perlin, S, Is Adrenochrome Present in the Blood? Am J Psychiat 115162 (1958)

7 Vogt, M Catecholammes in Brain Pharmacol Rev 11483 (1959)

8 Arouini, A \& Ardurni, M G Effect of Drugs and Metabolic Alterations on Brain Stem Arousal Mechanism J Pharmacol \& Exper Therap 11076 (1954)

9 Dell, $\mathrm{P}$, Bonvallet, M, \& Hugelin, A. Tonus sympathique, adrénaline et contrôle retzculaire de la motncité spinale E E G Clin Neurophysiol 6599 (1954)

10 Ingvar, D H \& Soderberg, U A New Method for Measuring Cerebral Blood Flow in Relation to the Electroencephalogram $\mathbb{E} \mathbb{E}$ Clin Neurophysiol 8403 (1956)

11 Brodie, B B, Spector, S, \& Srone, P A Intelaction of Drugs with Norepinephrine in the Brain Pharmacol Rev 11548 (1959)

12 Hess, W $R$ Diencephalon Autonomic and Extrapyramidal Functions Monogiaph in Biol \& Med, Vol 3 New York Grune \& Stratton (1954)

13 Himwich, H E Psychopharmacologic Drugs Science 12750 (1958)

14 Apten, J T Analeptic Action of Lysergic Acid Diethylamide (LSD-25) agamst Pentobarbital A M A Arch Neurol \& Psychiat 79711 (1958)

15 Dobirin, A B \& Harland, I H Drugs Which Stimulate Affective Behaviour 1 Action of Lysergic Acid Diethylamide (LSD-25) against Thiopentone Anaesthesia in Dogs Anaesthesia $15 \quad 48$ (1960)

16 Dobkin, A B Drugs Which Stımulate Affectuve Behaviour 2 Comparison of the Analeptic Effect of d'Amphetamine, Bemignde with Amiphenazole, Methylphenidylacetate, Iproniazid, Micoren and RP 8228 Anaesthesia 15146 (1960)

17 Drugs Which Stimulate Affective Behaviour 3 Companson of the Effect of Picrotoxin, Pentylenetetrazol, Bemignde, Pipradrol, Ectylurea, Vanllic Acid Diethylamide and Deanol Anaesthesia 15273 (1960)

18 Dobirin, A B \& Bries, $\mathbb{P}$ H The Interaction of Vasopressor Drugs with Halogenated Anaesthetics In preparation

19 The Interaction of Vasopressor Drugs with Innovar Anaesthesia In preparation

20 Brasczo, $H$ \& Cirnusier, T $L$ The Decarboxylation of Amino Acids Related to Tyrosine and their Awakening Action in Reserpine-Treated Mice J Physiol 151 272 (1960)

21 Chrustel, $T$ L Awakening Action of Denvatives of Phenylalanine In Adrenergic Mechanisms, ed I $\mathbb{R}$ Vane et al, p 440 London Churchill Ltd (1980)

22 Axempod, J, Whitrey, L G, \& Herting, $G$ Effect of Psychotropic Drugs on the Uptake of $H^{3}$-Norepinephrine by Tissues Science 133383 (1961)

23 BuRN, I H \& RAND, M The Action of Sympathommetc Ammes m Anmals Treated with Reserpine J Physiol 144314 (1958)

24 RcinerT, $H$ The Depolanzing and Blocking Action of Amphetamine in the Cat's Supenor Cervical Ganglion In Adrenergic Mechanisms, ed $J \mathbb{R}$ Vane et al, $p$ Churchull Ltd (1960)

25 Eysenck, H J Personality and Drug Effects In Expenments with Drugs, Chap 1 Oxford, England Pergamon Press (1963)

26 Rothbatime, A B Studies on the Adrenaline-Sensitive Component of the Reticular Activatung System E E Clin Neurophysiol 8603 (1956)

27 Goldstein, I \& MuNOz, $G$ Influence of Adrenergic Stmulant and Blocking Drugs on Cerebral Electrical Activity in Curarized Animals J Pharmacol \& Exper Therap 132 345 (1961)

28 BradiEx, P B Electrophysiological Evidence Relating to the Role of Adrenaline in the Central Nervous System In Adrenergic Mechanisms, ed J $\mathbb{R}$ Vane el al, pp 410-420 London Churchill Ltd (1960) 
29 CAPON, A Analyse de l'effet d'éveil exercé par l'adrénaline et d'autres ammes sympathcomimetiques sur l'electrocorticogramme du lapin non-narcosité Arch Int Pharmacodyn $127141^{\prime}(1960)$

30 Sokolorf, $L$ The Action of Drugs on the Cerebral Curculation Pharmacol Rev 11: 1 (1959)

31 Carlsson, A, Lindquist, M, \& Magnusson, $T$ 3,4-I Dihydroxyphenylalanine and 5Hydroxytryptophan as Reserpme Antagonists Nature 180 1200 (1957)

32 Carisson, A The Occurrence, Distribution and Physiological Role of Catecholammes un the Nervous System Pharmacol Rev 11490 (1959).

33 Rotriballer, A B The Effects of Catecholamines on the Central Nervous System. Pharmacol Rev 11494 (1959)

34 MeDonatd, $R$ D Personal communicaton (1964)

35 SMrTH, C B \& Dews, P $\mathbb{B}$ Antagonism of Locomotor Sippressant Effects of Reserpine in Mice Psychopharmacologia 355 (1962)

36 Randrut, A, Munisvad, I, \& UDSEN, P Adrenergic Mechanisms and AmphetammeInduced Abrormal Behavour Acta Pharmacologia et Tonlicol 20145 (1983)

37 Conver, A $H$, DAvison, $C$, CAstel, $\mathbb{R}$, \& Burns, J Adaptive Increases in Drug. Metabolizing Enzymes Induced by Phenobarbital and Dther Drugs I Pharmacol \& Exper Therap 130 1 (1980)

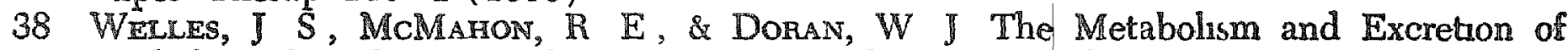
Meihohexital in the Rat and Dog J Pharmacol \& Exper Therap 139166 (1963) 